\title{
Classification of Pseudomonas diminuta Leifson and Hugh 1954 and Pseudomonas vesicularis Büsing, Döll, and Freytag 1953 in Brevundimonas gen. nov. as Brevundimonas diminuta comb. nov. and Brevundimonas vesicularis comb. nov., Respectively
}

\author{
P. SEGERS, ${ }^{1}$ M. VANCANNEYT, ${ }^{1}$ B. POT, ${ }^{1}$ U. TORCK, ${ }^{1}$ B. HOSTE, ${ }^{1}$ D. DEWETTINCK, ${ }^{1}$ \\ E. FALSEN ${ }^{2}$ K. KERSTERS, ${ }^{1}$ AND P. DE VOS ${ }^{1 *}$ \\ Laboratorium voor Microbiologie, Universiteit Gent, B-9000 Ghent, Belgium, ${ }^{1}$ and Culture Collection, \\ Department of Clinical Bacteriology, University of Göteborg, S-413 46 Göteborg, Sweden ${ }^{2}$
}

\begin{abstract}
The taxonomic positions of strains previously assigned to Pseudomonas diminuta and Pseudomonas vesicularis were investigated by a polyphasic approach. The results of DNA-rRNA hybridization studies indicated that these two species belong to a separate genus in the $\alpha$ subclass (rRNA superfamily IV) of the Proteobacteria, for which the name Brevundimonas is proposed. Genus delineation and species delineation were determined by comparing the results of numerical analyses of whole-cell protein patterns, fatty acid compositions, and phenotypic characteristics and by measuring DNA base ratios and degrees of DNA relatedness. Taxonomic characteristics of Brevundimonas diminuta and Brevundimonas vesicularis strains were compared with characteristics of reference strains belonging to the following phylogenetically related taxa: a group of organisms gathered in Enevold Falsen group 21, the genera Sphingomonas and Rhizomonas, and the generically misclassified organisms [Pseudomonas] echinoides and "[Pseudomonas] riboflavina."
\end{abstract}

The original description of the genus Pseudomonas Migula 1894 allowed the inclusion of an extremely wide variety of aerobic gram-negative bacteria (24). The use of rRNA-based techniques, such as DNA-rRNA hybridization $(12-14,26)$ and 16S rRNA oligonucleotide cataloging (42), revealed the phylogenetic distribution of members of the genus Pseudomonas sensu Palleroni (24) in the $\alpha, \beta$, and $\gamma$ subclasses of the Proteobacteria (6). The phylogenetic heterogeneity of the genus Pseudomonas was also supported by the finding that there are enzymatic differences in aromatic amino acid biosynthesis (4). Therefore, the authentic genus Pseudomonas should be restricted to Palleroni's rRNA group I $(12,24)$. Various pseudomonads belonging to the other rRNA groups have previously been allocated to other genera (33) or elevated to genus rank $(25,38,40,43,44)$.

The rRNA group IV members [Pseudomonas] diminuta and [Pseudomonas] vesicularis, often referred to as the diminuta group $(1,16)$, occupy a unique taxonomic position among the pseudomonads (genus names in brackets indicate that an organism is generically misclassified). Both of these species can be distinguished from most gram-negative bacteria by a combination of characteristics, including flagellar morphology, nutritional properties, acid tolerance, type of pigmentation, nature of carbon reserve materials, and DNA base composition $(1,16,24)$. The results of DNA-rRNA hybridization experiments (12), 16S rRNA cataloging (42), and 16S rRNA sequencing $(30)$ have indicated that $[P$. $]$ diminuta occupies a separate branch in rRNA superfamily IV (the $\alpha-2$ subclass) of the Proteobacteria.

Although $[P$.$] diminuta and [P$.$] vesicularis are genotypically$ easily differentiated from other taxa belonging to rRNA super-

* Corresponding author. Mailing address: Laboratorium voor Microbiologie, Universiteit Gent, K.L. Ledeganckstraat, 35, B-9000 Ghent, Belgium. family IV, genus delineation and species delineation based on phenotypic characteristics are less clear. Therefore, some strains were preliminarily classified into EF group 21, a heterogeneous group containing organisms that are phenotypically similar to $[P$.$] vesicularis and Sphingomonas paucimobilis$ (formerly [Pseudomonas] paucimobilis) (15). The taxonomic positions of these taxa and of representatives of the genera Sphingomonas and Rhizomonas $(34,44)$ were examined in this study. The phylogenetic positions of two other misclassified organisms, [Pseudomonas] echinoides and "[Pseudomonas] riboflavina," were also determined (names in quotation marks are invalid names).

On the basis of both genotypic and phenotypic characteristics, we propose that $[P$. $]$ diminuta and $[P$.] vesicularis should be classified in the new genus Brevundimonas. The names Brevundimonas diminuta comb. nov. and Brevundimonas vesicularis comb. nov. are used below for $[P$.$] diminuta and [P$. vesicularis, respectively.

\section{MATERIALS AND METHODS}

Strains used. The designations and sources of the strains which we used are listed in Table 1 . All strains were checked for purity by plating and microscopic examination. The cells were cultivated on nutrient agar at $28^{\circ} \mathrm{C}$ for 1 or 2 days.

Polyacrylamide gel electrophoresis of whole-cell proteins. The methods used for preparation and electrophoresis of sodium dodecyl sulfate protein extracts have been described previously (35). The gel electrophoretic profiles were recorded densitometrically, stored as normalized records in a PC-AT computer, and analyzed numerically with the GelCompar software package (Applied Maths, Kortrijk, Belgium). The levels of similarity between pairs of traces were calculated by using the Pearson product-moment correlation coefficient $(r)$, 
TABLE 1. Strains used, other strain designations, and sources of isolation

\begin{tabular}{|c|c|c|c|}
\hline Strain $^{a}$ & Other designation $(\mathrm{s})^{a}$ & Name as received & Source \\
\hline \multicolumn{4}{|l|}{ Brevundimonas diminuta strains } \\
\hline LMG $2089 \mathrm{t} 1^{\mathrm{T}}$ & $\begin{array}{l}\text { ATCC } 11568^{\mathrm{T}}, \text { CCEB } 513^{\mathrm{T}}, \\
\text { CCUG } 1427^{\mathrm{T}}, \text { LMG } 1793^{\mathrm{T}}\end{array}$ & Pseudomonas diminuta & Fresh water \\
\hline LMG 2337 & $\begin{array}{l}\text { NCTC 9239, CCUG 1797, } \\
\text { ATCC } 14736\end{array}$ & Pseudomonas diminuta & Blood, patient with endocarditis \\
\hline LMG 3503 & NCIB 9407, CCUG 28327 & Pseudomonas diminuta & \\
\hline LMG 9559 & CCUG 269C & Pseudomonas diminuta & Human urine (Göteborg, Sweden) \\
\hline LMG 9561 & ATCC 13184, CCUG 2031 & Pseudomonas diminuta & Buccal cavity \\
\hline LMG 9562 & CCUG 2868, NCIB 10329 & Pseudomonas diminuta & Unknown \\
\hline LMG 9563 & CCUG 14202 & Pseudomonas diminuta & Blood plasma (Slagelse, Denmark) \\
\hline LMG 10743 & $\begin{array}{l}\text { CCUG } 24715 \text {, ATCC } 19146, \\
\text { DSM } 1635\end{array}$ & Pseudomonas diminuta & Contaminant of Bacillus cereus culture \\
\hline LMG 11061 & CCUG 154 & Pseudomonas diminuta & Contaminated egg yolk (Göteborg, Sweden) \\
\hline LMG 11062 & CCUG 1376 & Pseudomonas diminuta & Unknown (Orebro, Sweden) \\
\hline LMG 11063 & CCUG 14332 & Pseudomonas diminuta & Humidifier, water (Strasbourg, France) \\
\hline LMG 11064 & CCUG 25811 & Pseudomonas diminuta & Human ear (Boras, Sweden) \\
\hline LMG 11065 & CCUG 1189 & Pseudomonas diminuta & Unknown \\
\hline LMG 11136 & CCUG 28328 & Pseudomonas diminuta & Hemoculture (Hospital, Brussels, Belgium) \\
\hline LMG 11137 & CCUG 28329 & Pseudomonas diminuta & Hemoculture (Hospital, Brussels, Belgium) \\
\hline LMG 11138 & CCUG 28330 & Pseudomonas diminuta & Pleural liquid (Hospital, Brussels, Belgium) \\
\hline LMG 11139 & CCUG 28331 & Pseudomonas diminuta & Hemoculture (Hospital, Brussels, Belgium) \\
\hline LMG 11147 & CCUG 248 & Pseudomonas diminuta & Water (Göteborg, Sweden) \\
\hline LMG 11149 & CCUG 1364 & Pseudomonas diminuta & Unknown (Orebro, Sweden) \\
\hline \multicolumn{4}{|l|}{ Brevundimonas vesicularis strains } \\
\hline LMG $2350^{\mathrm{T}}$ & $\begin{array}{l}\text { ATCC } 11426^{\mathrm{T}}, \text { CCUG } \\
2032^{\mathrm{T}}, \text { NCTC } 10900^{\mathrm{T}}\end{array}$ & Pseudomonas vesicularis & Leech (Hirudo sp.), urinary bladder, epithelium \\
\hline LMG 9565 & CCUG $14431 \mathrm{~A}$ & Pseudomonas vesicularis & Leech (Hirudo sp.), urinary bladder? \\
\hline LMG 9566 & CCUG 14807 & Pseudomonas vesicularis & Leg wound (United States) \\
\hline LMG 11067 & CCUG 14205 & Pseudomonas vesicularis & Denmark \\
\hline LMG 11068 & CCUG 14806 & Pseudomonas vesicularis & Environment (United States) \\
\hline LMG 11140 & CCUG 28336 & Pseudomonas vesicularis & Vaginal swab (Hospital, Brussels, Belgium) \\
\hline LMG 11141 & CCUG 28337 & Pseudomonas vesicularis & Pleural liquid (Hospital, Brussels, Belgium) \\
\hline LMG 11142 & Hansen 1220 & Pseudomonas vesicularis & Hemoculture (Hospital, Brussels, Belgium) \\
\hline LMG 11148 & CCUG 1314 & Pseudomonas vesicularis & Unknown (Denmark?) \\
\hline LMG 9554 & CCUG 14808 & EF group 21 & Blood (United States) \\
\hline \multicolumn{4}{|l|}{ Brevundimonas sp. strains } \\
\hline LMG 9564 & CCUG 14203 & Pseudomonas vesicularis & Denmark \\
\hline LMG 9567t1 & CCUG 14827, CCM 3400 & Pseudomonas vesicularis & Oral contraceptives \\
\hline LMG 11070 & CCUG 22949 & Pseudomonas vesicularis & Water, deep bore hole (Göteborg, Sweden) \\
\hline Brevundimonas-like strain LMG 11050 & CCUG 26751 & EF group 21 & Human blood (Göteborg, Sweden) \\
\hline Sphingomonas paucimobilis LMG $1227^{\mathrm{T}}$ & $\begin{array}{c}\text { NCTC } 11030^{\mathrm{T}}, \text { CCUG } \\
6518^{\mathrm{T}}, \text { DSM } 1098^{\mathrm{T}}\end{array}$ & Sphingomonas paucimobilis & Hospital respirator (London, United Kingdom) \\
\hline [Sphingomonas] capsulata LMG $2830^{\mathrm{T}}$ & $\begin{array}{l}\text { ATCC } 14666^{\mathrm{T}}, \text { CCUG } \\
17697^{\mathrm{T}}, \text { DSM } 30196^{\mathrm{T}}, \\
\text { IFO } 12533^{\mathrm{T}}\end{array}$ & Sphingomonas capsulata & Stocked distilled water \\
\hline Sphingomonas adhaesiva LMG $10922^{\mathrm{T}}$ & CCUG $27290^{\mathrm{T}}$ & Sphingomonas adhaesiva & Sterile water used before surgery \\
\hline $\begin{array}{l}\text { Sphingomonas parapaucimobilis } \\
\text { LMG } 10923^{\mathrm{T}}\end{array}$ & CCUG $27291^{\mathrm{T}}$ & $\begin{array}{l}\text { Sphingomonas parapauci- } \\
\text { mobilis }\end{array}$ & Urine \\
\hline Sphingomonas sanguis LMG $10925^{\mathrm{T}}$ & CCUG $27654^{\mathrm{T}}$ & Sphingomonas genospecies 1 & Blood (United States?) \\
\hline Sphingomonas terrae LMG 10924 & CCUG 27293 & Sphingomonas genospecies 2 & Sterile water used before surgery \\
\hline \multicolumn{4}{|l|}{ [Sphingomonas] yanoikuyae strains } \\
\hline LMG $11252^{\mathrm{T}}$ & CCUG $28380^{\mathrm{T}}$ & Sphingomonas yanoikuyae & Human (Copenhagen, Denmark) \\
\hline LMG 9552 & CCUG 14335 & EF group $21 \mathrm{D}$ & Hospital dialysis equipment, water \\
\hline LMG 9553 & CCUG 14336A & EF group $21 \mathrm{D}$ & Hospital dialysis equipment, water \\
\hline LMG 11066 & CCUG 14204 & Pseudomonas vesicularis-like & Denmark \\
\hline \multicolumn{4}{|l|}{ Rhizomonas-Sphingomonas-like strains } \\
\hline LMG 11049 & CCUG 25702 & EF group 21 & Cerebrospinal fluid (Göteborg, Sweden) \\
\hline LMG 11069 & CCUG 25098 & Pseudomonas vesicularis-like & Water, shower in hospital (Göteborg, Sweden) \\
\hline LMG 9555 & CCUG 18318 & EF group $21 \mathrm{~B}$ & Pleural fluid (Göteborg, Sweden) \\
\hline LMG 11151 & CCUG 18056 & Pseudomonas paucimobilis & Tap water (Göteborg, Sweden) \\
\hline "[Pseudomonas] riboflavina" LMG $2277^{\mathrm{T}}$ & ATCC $9526^{\mathrm{T}}$ & Pseudomonas riboflavina & Riboflavin-rich soil \\
\hline Sphingomonas sp. strain LMG $2181^{\mathrm{T}}$ & ATCC $14820^{\mathrm{T}}$ & Pseudomonas echinoides & Laboratory contaminant of nutrient agar plate \\
\hline
\end{tabular}

${ }^{a}$ ATCC, American Type Culture Collection, Rockville, Md.; CCM, Czech Collection of Microorganisms, Brno, Czech Republic; CCUG, Culture Collection of the University of Göteborg, Department of Clinical Bacteriology, University of Göteborg, Göteborg, Sweden; DSM, Deutsche Sammlung von Mikroorganismen, Braunschweig, Germany; IFO, Institute for Fermentation, Osaka, Japan; LMG, Culture Collection, Laboratorium voor Microbiologie, University of Ghent, Ghent, Belgium; NCIB, National Collection of Industrial Bacteria, Aberdeen, Scotland; NCTC, National Collection Type Cultures, Central Public Health Laboratory, London, England. 
and a cluster analysis was performed by using the unweighted average linkage algorithm (36).

Gas chromatographic analysis of methylated fatty acids. Bacteria were grown at $28^{\circ} \mathrm{C}$ on Trypticase soy agar containing $3.0 \%(\mathrm{wt} / \mathrm{vol})$ Trypticase soy broth (BBL) and $1.5 \%(\mathrm{wt} / \mathrm{vol})$ Bacto Agar (Difco). After 24 h of growth approximately $60 \mathrm{mg}$ (wet weight) of cells was harvested from the most dilute quadrant exhibiting confluent growth. The methods used to extract fatty acids, prepare methyl esters, and separate methyl esters by gas chromatography have been described previously (37). Fatty acid methyl ester fingerprints were identified with the Microbial Identification System software package (MIS version 3.7; Microbial ID, Inc., Newark, Del.). A statistical program, CLUS (Microbial ID, Inc.), was used to perform a cluster analysis of the strains.

Phenotypic characterization. All 105 conventional tests used were performed as described previously (15). The carbon assimilation tests were performed with API 50CH, API 50AO, and API 50AA galleries (API Systems, Montalieu-Vercieu, France) according to a standardized procedure (19). Levels of similarity between isolates were calculated by using the simple matching coefficient of Sokal and Michener (29), and a cluster analysis was performed by the unweighted average pair group method (28), using the Clustan 2.1 program (41) and the Siemens model 7551 computer of the Centraal Digitaal Rekencentrum, Universiteit Gent, Ghent, Belgium.

DNA-DNA hybridization. Degrees of DNA-DNA binding, expressed as percentages, were determined spectrophotometrically by using the initial renaturation method of De Ley et al. (7) and the equipment and method described by Willems et al. (38).

DNA base composition. High-molecular-weight DNAs from representative strains of each of the clusters were isolated by the method of Marmur (21). The average guanine-plus-cytosine $(\mathrm{G}+\mathrm{C})$ contents were determined by the thermal denaturation method (10) and were calculated according to the equation of De Ley (5).

DNA-rRNA hybridization. DNAs were made single stranded and fixed on cellulose nitrate filters (9). ${ }^{3} \mathrm{H}$-labeled rRNAs from the type strains of $B$. vesicularis and $S$. paucimobilis were isolated and purified as described by De Ley and De Smedt (8). Hybridization between the 16S rRNA probes and filter-fixed DNAs was carried out as described previously (8). The temperature at which one-half of each DNA-rRNA hybrid was thermally denatured $\left(T_{m(e)}\right)$ was used to construct an rRNA dendrogram.

Analysis of cellular polyamines. Polyamine profiles were determined by a high-performance liquid chromatographybased technique described by Busse and Auling (3), which was slightly modified as described by Yang et al. (45). The polyamine contents are reported below in micromoles per gram (wet weight).

\section{RESULTS}

Polyacrylamide gel electrophoresis of whole-cell proteins. The results of a cluster analysis of the protein profiles of $B$. diminuta, B. vesicularis, Sphingomonas, Rhizomonas, and some related strains are shown in Fig. 1. Considerable heterogeneity was observed among the profiles of $B$. vesicularis strains. At an $r$ level of 0.82 two subgroups could be delineated; one of these two subgroups contained five strains (LMG $2350^{\mathrm{T}}[\mathrm{T}=$ type strain], LMG 11068, LMG 9566, LMG 11067, and LMG 9565), and the other contained four strains (LMG 9554, LMG 11142, LMG 11148, and LMG 11140). The profiles of one B. vesicularis strain (LMG 11141), three Brevundimonas sp. strains

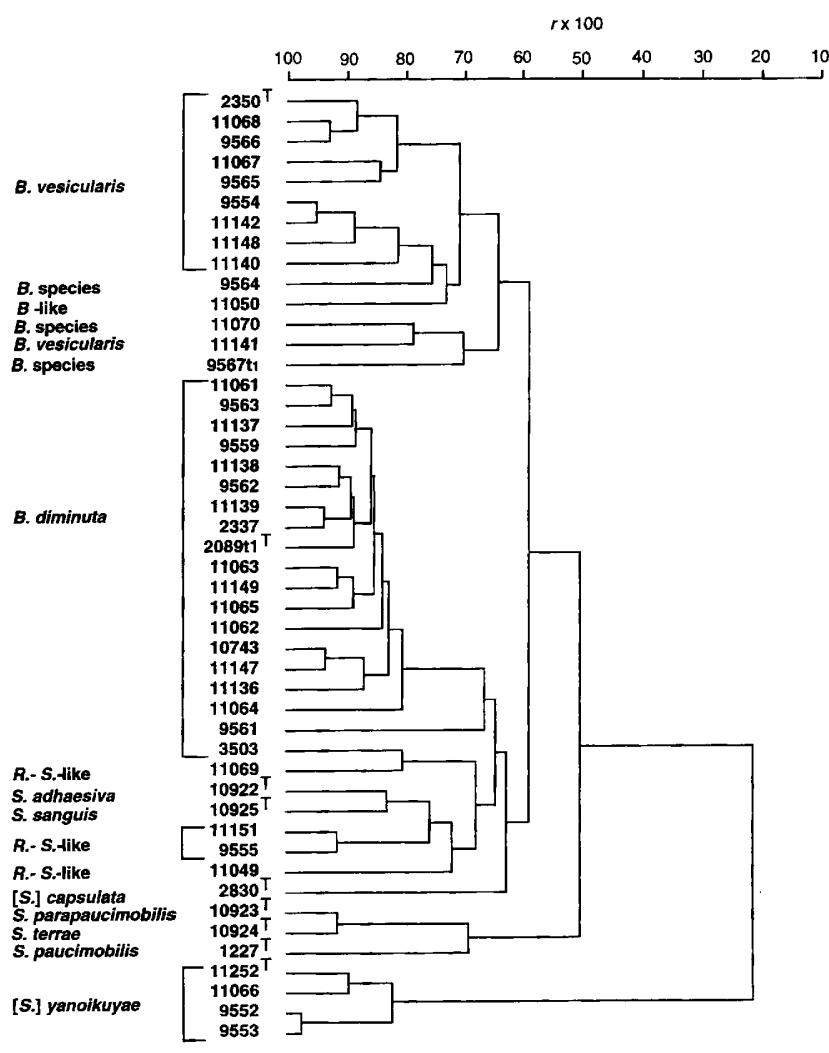

FIG. 1. Dendrogram based on the results of an unweighted pair group average linkage cluster analysis of correlation coefficients $(r)$ obtained by using the sodium dodecyl sulfate-polyacrylamide gel electrophoresis protein patterns of all of the strains studied. Abbreviations: B., Brevundimonas; R., Rhizomonas; S., Sphingomonas.

(LMG 9564, LMG 9567t1, and LMG 11070), and one unclassified strain (LMG 11050) were linked at $r$ levels ranging from 0.65 to 0.75 . A more homogeneous protein pattern was found for the strains of $B$. diminuta; 17 strains were grouped in a single cluster $(r \geq 0.82$ ), and only 2 strains (LMG 9561 and LMG 3503) occupied a separate position. In the genus Sphingomonas the reference strains of some species could not be characterized individually; similar protein profiles were found for the type strains of Sphingomonas adhaesiva and Sphingomonas sanguis ( $r=0.82)$ and for Sphingomonas parapaucimobilis and Sphingomonas terrae $(r=0.91)$. The type strains of [Sphingomonas] capsulata and $S$. paucimobilis produced unique protein patterns. Two of four strains related to the genera Sphingomonas and Rhizomonas (strains LMG 11069 and LMG 11049) produced unique protein fingerprints, while the other two strains (LMG 11151 and LMG 9555) formed a distinct electrophoretic cluster. The four strains of [Sphingomonas] yanoikuyae produced very similar protein fingerprints that were clearly distinct from the fingerprints of the other strains studied.

Gas chromatographic analysis of methylated fatty acids (fatty acid methyl esters). The cellular fatty acid compositions of Brevundimonas strains and reference strains of phylogenetically related taxa are shown in Table 2. As shown in Fig. 2, a numerical analysis of the results revealed several clusters. All Brevundimonas strains grouped into two large clusters. One of these contained all $B$. vesicularis strains, three Brevundimonas sp. strains (LMG 9564, LMG 11070, and LMG 9567t1), and 


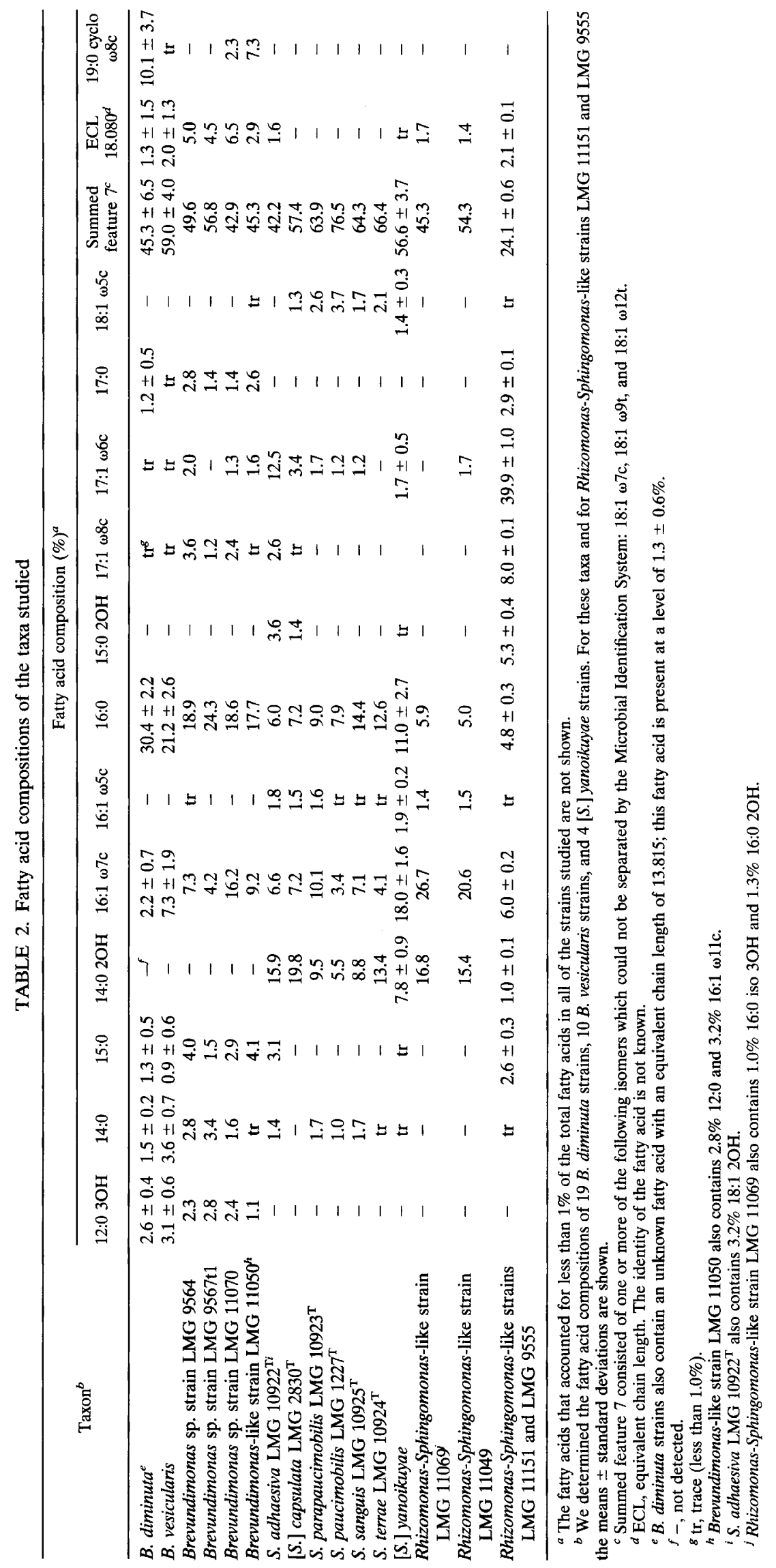




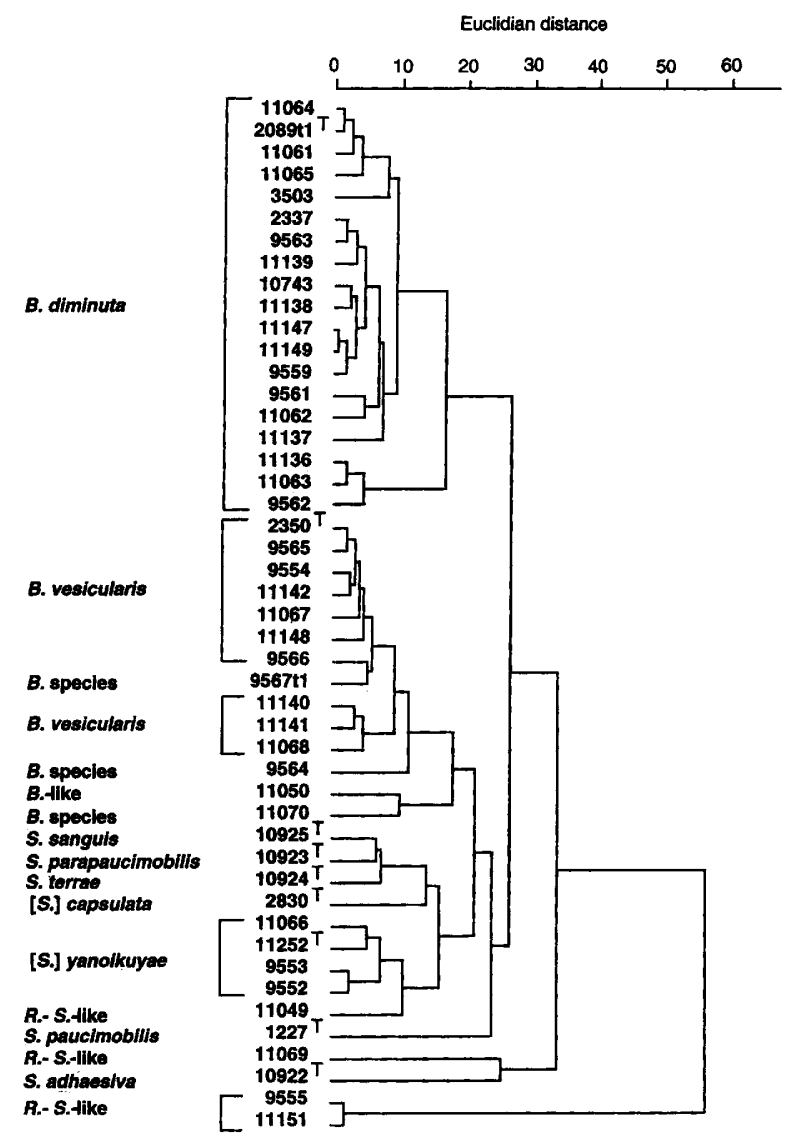

FIG. 2. Dendrogram obtained after numerical analysis of fatty acid methyl ester profiles. Abbreviations are explained in the legend to Fig. 1.

strain LMG 11050. The other large cluster contained all $B$. diminuta strains, including strain LMG 3503. All Brevundimonas strains contained two major fatty acids, $16: 0$ and 18:1 (summed feature 7), and the following minor components: 12:0 $30 \mathrm{O}, 14: 0,15: 0,16: 1 \omega 7 \mathrm{c}, 17: 0$, and an unknown fatty acid with an equivalent chain length of 18.080 . $B$. diminuta was easily differentiated from $B$. vesicularis strains by the presence of high percentages of 19:0 cyclo w8c. Brevundimonas strains were differentiated from Sphingomonas and Rhizomonas strains by the presence of 12:0 $30 \mathrm{OH}$ and by the absence of $14: 02 \mathrm{OH}$. The type strains of $S$. parapaucimobilis, $S$. sanguis, and $S$. terrae grouped together (Fig. 2), while those of $S$. adhaesiva, $[S$. $]$ capsulata, and $S$. paucimobilis occupied distinct positions. The strains of [S.] yanoikuyae formed a separate cluster. Two of four strains related to the genera Sphingomonas and Rhizomonas formed a cluster (LMG 9555 and LMG 11151), while LMG strain 11049 was rather close to [S.] yanoikuyae and strain LMG 11069 occupied a separate position in the fatty acid methyl ester dendrogram.

Numerical analysis of phenotypic features. All Brevundimonas, Sphingomonas, Rhizomonas, and related strains studied were characterized phenotypically. Features that differentiate taxa within the genus Brevundimonas are shown in Table 3, and the results of a numerical analysis of the data are shown in a dendrogram in Fig. 3. All $B$. diminuta strains exhibited very similar, restricted growth on most carbohydrates (Table 3). A separate cluster was formed by all of the $B$. vesicularis strains (Fig. 3); these strains were differentiated from B. diminuta by the assimilation of particular sugars and by the lack of growth on several organic and amino acids (Table 3). The Brevundimonas sp. strains (LMG 11070, LMG 9564, and LMG 9567t1) grouped at the border of the $B$. vesicularis cluster. In this analysis, most of the Sphingomonas type strains occupied distinct positions; the exceptions were the type strains of $S$. sanguis and $S$. terrae, which grouped together. Well-defined clusters were formed by the four strains of $[S$.] yanoikuyae and by two strains related to the genera Rhizomonas and Sphingomonas (LMG 9555 and LMG 11151). The other strains (LMG 11050, LMG 11069, and LMG 11049) did not group in one of the clusters discussed above.

DNA-DNA hybridization. On the basis of the results of the numerical analyses described above, representative strains were selected for DNA-DNA hybridization experiments. Figure 4 shows that both $B$. diminuta and $B$. vesicularis are distinct and well-characterized genomic species; the DNA-binding values for these species ranged from 41 to $73 \%$ and from 52 to $68 \%$, respectively. Two Brevundimonas sp. strains (LMG 11070 and LMG 9564) exhibited no significant levels of DNA binding with $B$. diminuta and $B$. vesicularis strains. Two other strains, Brevundimonas sp. strain LMG $9567 \mathrm{t} 1$ and Brevundimonas-like strain LMG 11050, exhibited no significant levels of DNA binding with $B$. vesicularis. Among the other strains investigated, two DNA homology groups could be differentiated: one of these groups contained [S.] yanoikuyae strains, and the other contained strains LMG 9555 and LMG 11151, which were rather distantly related to the genera Sphingomonas and Rhizomonas (see below).

DNA base composition. The average $\mathrm{G}+\mathrm{C}$ contents of representative strains are shown in Table 4. The genera Brevundimonas and Sphingomonas and their respective species could not be differentiated on the basis $\mathrm{G}+\mathrm{C}$ contents. The DNA base ratios ranged from 65.4 to $67.9 \mathrm{~mol} \%$ for the genus Brevundimonas and from 65.2 to $67.9 \mathrm{~mol} \%$ for the genus Sphingomonas. [S.] yanoikuyae strains had somewhat lower $\mathrm{G}+\mathrm{C}$ contents ( 63 to $65 \mathrm{~mol} \%$ ).

DNA-rRNA hybridization. ${ }^{3} \mathrm{H}$-labeled rRNAs from $B$. vesicularis LMG $2350^{\mathrm{T}}$ and $S$. paucimobilis LMG $1227^{\mathrm{T}}$ were hybridized with DNAs from strains selected after interpretation of different fingerprint data. Our results (Table 4 and Fig. 5) demonstrated that all of the Brevundimonas strains examined were located on a single, separate rRNA branch in rRNA superfamily IV (the $\alpha$ subclass) of the Proteobacteria. Two subgroups were delineated; one group contained all of the $B$. vesicularis strains and three Brevundimonas sp. strains (LMG 9567t1, LMG 9564, and LMG 11070) $\left[T_{m(e)}\right.$ range, 81.4 to $79.3^{\circ} \mathrm{Cl}$, and the other group contained all of the $B$. diminuta strains $\left[T_{m(e)}\right.$ range, 78.0 to $\left.75.9^{\circ} \mathrm{C}\right]$. Strain LMG 11050 was located at the base of the Brevundimonas rRNA branch and fell outside the range of the genus.

The phylogenetic positions of the Sphingomonas and Rhizomonas reference strains have been discussed elsewhere (34), and the $T_{m(e)}$ values of strains LMG 9555, LMG 11049, and LMG 11069 indicated that these organisms are related to these genera. Additional hybridization data will be necessary to decide whether these strains are members of separate genera. $\left[P\right.$.] echinoides LMG $2181^{\mathrm{T}}$ was located on the Sphingomonas branch and should be assigned to this genus; its exact species status needs further study. The position of " $P$. $]$ riboflavina" LMG $2277^{\mathrm{T}}$ remains unclear at the border of rRNA superfamily IV.

Analysis of cellular polyamines. The polyamine concentrations found in Brevundimonas, Sphingomonas, Rhizomonas, and related strains are shown in Table 5. All of the strains studied were characterized by the occurrence of significant 
TABLE 3. Characteristics that differentiate Brevundimonas named and unnamed species and Brevundimonas-like strain LMG $11050^{a}$

\begin{tabular}{|c|c|c|c|c|c|c|}
\hline Characteristic & $\begin{array}{l}\text { B. diminuta } \\
(n=19)^{b}\end{array}$ & $\begin{array}{l}\text { B. vesicularis } \\
(n=10)^{b}\end{array}$ & $\begin{array}{l}\text { Brevundimonas } \\
\text { sp. strain } \\
\text { LMG } 9564\end{array}$ & $\begin{array}{l}\text { Brevundimonas } \\
\text { sp. strain } \\
\text { LMG 9567t1 }\end{array}$ & $\begin{array}{l}\text { Brevundimonas } \\
\text { sp. strain } \\
\text { LMG } 11070\end{array}$ & $\begin{array}{l}\text { Brevundimonas-like } \\
\text { strain LMG } 11050\end{array}$ \\
\hline $\begin{array}{l}\text { Yellow or orange } \\
\text { carotenoid pigment }\end{array}$ & - & $\mathrm{v}$ & - & + & - & - \\
\hline Cystine requirement ${ }^{c}$ & + & - & ND & ND & ND & ND \\
\hline Hydrolysis of esculin ${ }^{d}$ & - & + & + & + & + & + \\
\hline \multicolumn{7}{|l|}{ Assimilation of ${ }^{d}$ : } \\
\hline D-Xylose & - & - & + & - & - & - \\
\hline Adonitol & - & - & - & - & - & + \\
\hline D-Mannose & - & - & + & - & - & - \\
\hline D-Glucose & - & + & + & + & + & - \\
\hline D-Galactose & - & + & + & + & + & - \\
\hline Amygdalin & - & - & - & - & - & + \\
\hline Arbutin & - & - & - & - & + & + \\
\hline Salicin & - & - & - & - & + & + \\
\hline Maltose & - & + & + & + & + & - \\
\hline Trehalose & - & - & - & + & - & - \\
\hline Propionate & - & - & - & + & - & _- \\
\hline Isobutyrate & - & - & - & + & - & - \\
\hline$n$-Caproate & - & - & - & - & + & - \\
\hline Adipate & - & - & - & - & - & + \\
\hline Pimelate & - & - & - & - & - & + \\
\hline Suberate & - & - & - & - & - & + \\
\hline Azelate & - & - & - & - & - & + \\
\hline Sebacate & - & - & - & - & - & + \\
\hline Glycine & - & - & + & - & - & - \\
\hline L-Histidine & + & - & - & - & - & - \\
\hline \multicolumn{7}{|l|}{ API ZYM reactions } \\
\hline Ester lipase (C8) & + & + & + & - & + & ND \\
\hline$\alpha$-Glucosidase & - & + & + & + & + & ND \\
\hline$\beta$-Glucosidase & - & - & + & - & + & ND \\
\hline $\begin{array}{l}\text { Occurrence of fatty acid } \\
\text { 19:0 cyclo } \omega 8 c\end{array}$ & + & - & - & - & + & + \\
\hline \multicolumn{7}{|l|}{ Occurrence of polyamines } \\
\hline Homospermidine & + & + & - & + & + & + \\
\hline Spermidine & $\operatorname{tr}$ & + & + & + & + & + \\
\hline $\begin{array}{l}T_{m(e)} \text { with } B . \text { vesicularis } \\
\text { LMG } 2350^{\mathrm{T}} \text { rRNA }\left({ }^{\circ} \mathrm{C}\right)\end{array}$ & $81.4-79.3$ & $78-75.9$ & 79.3 & 81.1 & 81.4 & 73.9 \\
\hline
\end{tabular}

${ }^{a}-, 90 \%$ of more of the strains are negative;,$+ 90 \%$ or more of the strains are positive; $\mathrm{v}$, variable; ND, not determined; tr, trace.

${ }^{b} n$ is the number of strains tested.

${ }^{c}$ Data from reference 1.

${ }^{d}$ Tests were performed with API 50CH, API 50AO, and API 50AA galleries.

amounts of homospermidine or spermidine or both. $B$. diminuta strains produced homospermidine as the major component (1.7 to $3.4 \mu \mathrm{mol} / \mathrm{g}$ [wet weight]) and trace amounts of spermidine. All of the $B$. vesicularis strains except strain LMG 9554 produced spermidine as the major component (1.6 to 2.5 $\mu \mathrm{mol} / \mathrm{g}$ [wet weight]), homospermidine as a minor component ( 0.1 to $0.5 \mu \mathrm{mol} / \mathrm{g}$ [wet weight]), and, in some cases, trace amounts of norspermidine, putrescine, and spermine. $B$. vesicularis LMG 9554 produced less spermidine $(0.6 \mu \mathrm{mol} / \mathrm{g}$ [wet weight]) and no homospermidine at all. Brevundimonas sp. strains LMG 9567t1 and LMG 11070 produced a polyamine pattern similar to that of the B. vesicularis strains. Brevundimonas sp. strain LMG 9564 produced only high amounts of spermidine $(4.2 \mu \mathrm{mol} / \mathrm{g}$ [wet weight]). Strain LMG 11050 was differentiated from $B$. vesicularis by the higher amounts of homospermidine that it produced.

All of the Sphingomonas strains except the [S.] capsulata and [S.] yanoikuyae strains produced significant amounts of homospermidine (1.8 to $5.0 \mu \mathrm{mol} / \mathrm{g}$ [wet weight]) and only trace amounts of spermidine. [S.] capsulata, $[S$.] yanoikuyae, and the Rhizomonas-Sphingomonas-like strains were easily differentiated because they produced high levels of spermidine ( 2.5 to $4.0 \mu \mathrm{mol} / \mathrm{g}$ [wet weight]) and no homospermidine.

\section{DISCUSSION}

Previously, 16S rRNA cataloging revealed that $[P$. $]$ diminuta and probably also $[P$.] vesicularis (although $[P$.$] vesicularis was$ not included in the previous rRNA sequence studies) phylogenetically belong to the $\alpha$ subclass of the Proteobacteria, whereas the authentic pseudomonads belong to the $y$ subclass (42). Analogous data were obtained in DNA-rRNA hybridization studies in which workers placed the diminuta group in rRNA superfamily IV and not in rRNA superfamily II $(12,24$, 26). These previous findings, together with the results of this study, support the proposal that $[P$. $]$ diminuta and $[P$.$] vesicu-$ laris deserve to be classified in a new genus, for which we propose the name Brevundimonas.

Recent 16S rRNA sequencing data, however, have shown that there is a close affiliation between $B$. diminuta and some Caulobacter strains (30). Definite conclusions concerning the taxonomic status of the genus Caulobacter cannot be drawn at this time because (i) on the basis of sequencing data (30) the Caulobacter strains that have been studied seem to be phylogenetically too heterogeneous to be members of one genus and (ii) rRNA sequence data for the type species (Caulobacter vibrioides) are not available. 


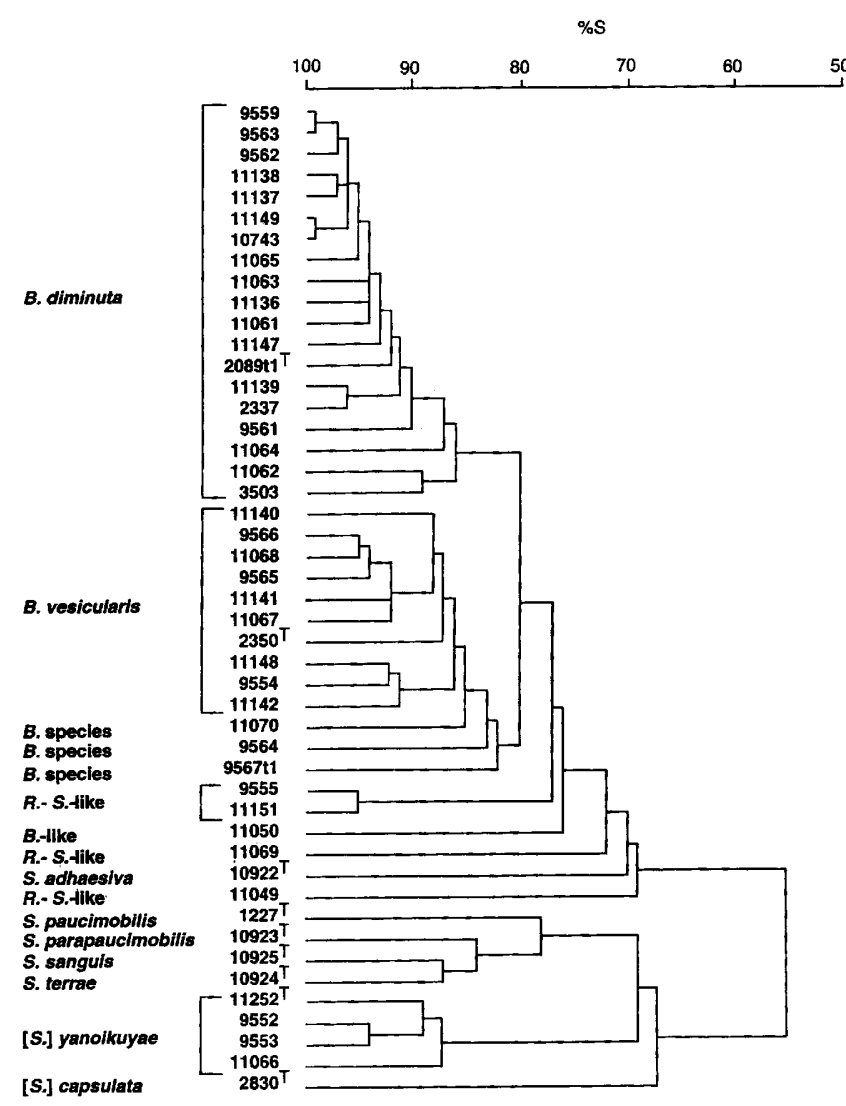

FIG. 3. Dendrogram obtained after an unweighted pair group cluster analysis of the similarity coefficients of the phenotypic data obtained for all of the strains investigated. We used 147 carbon assimilation tests to calculate the similarity coefficients $\left(S_{\mathrm{SM}}\right)$. Abbreviations are explained in the legend to Fig. 1.

Moreover, DNA-rRNA hybridization results obtained in this study indicated that Brevundimonas strains constitute a separate branch within rRNA superfamily IV (Fig. 5). This branch is equidistant from the following rRNA homology groups: (i) the family Acetobacteraceae, (ii) the genus Rhodobacter, (iii) the Rhodospirillum-Azospirillum group, (iv) the Bradyrhizobium-Rhodopseudomonas group, (v) the Agrobacte-

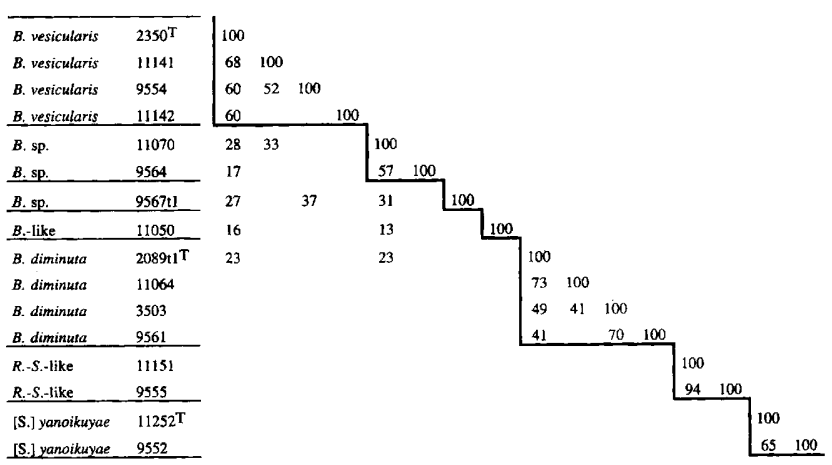

FIG. 4. DNA-DNA hybridization values for representative Brevundimonas strains. The levels of DNA relatedness are expressed as percentages of DNA binding. Abbreviations are explained in the legend to Fig. 1.
rium-Rhizobium group, and (vi) the Sphingomonas-Rhizomonas group (18).

The rRNA homology group comprising the genera Sphingomonas, Rhizomonas, and Zymomonas has been discussed elsewhere (34). We found during this taxonomic study of the diminuta group that four strains (LMG 9555, LMG 11049, LMG 11069, and LMG 11151) were located at the lower border of the $S$. paucimobilis rRNA branch. Furthermore, according to the rRNA hybridization data $[P$.] echinoides belongs to the genus Sphingomonas, while " $[P$. $]$ riboflavina" could not be classified more precisely in rRNA superfamily IV (Table 4) (14).

In addition to the genotypic evidence discussed above, a number of chemotaxonomic and other features confirmed the separate generic status of the genus Brevundimonas. Members of the genus Brevundimonas differ from the authentic pseudomonads by having short-wavelength polar flagella, restricted biochemical activity, and different polyamine and ubiquinone patterns, as well as different characteristic fatty acid compositions (Table 6). The first two characteristics also differentiate the genus from the family Comamonadaceae and the genus Burkholderia. Brevundimonas strains can be distinguished from the genus Caulobacter by the highly specific morphology of the organisms and by different biochemical activity and from the genera Sphingomonas and Rhizomonas by several phenotypic and genomic features. Previously published data indicate that the presence of sphingolipids and the fatty acid C14:0 $2 \mathrm{OH}$ is highly specific for the genera Sphingomonas and Rhizomonas (Table 6). Thus, the results of our polyphasic study show that members of the genus Brevundimonas form separate taxonomic entities that are based not only on genotypic characteristics but also on phenotypic and chemotaxonomic characteristics.

On the Brevundimonas rRNA branch, we delineated two similarity groups (Table 4) with $T_{m(e)}$ values ranging from 81.4 to $79.3^{\circ} \mathrm{C}$ and from 78.0 to $75.9^{\circ} \mathrm{C}$. The first group consists of the species $B$. vesicularis and three Brevundimonas strains which could not be classified as members of one of the recognized species, although a close resemblance to $B$. vesicularis could be deduced from the results obtained with several of the taxonomic methods used (see below). The second group contains $B$. diminuta. No significant differences in DNA base composition were observed between members of the two Brevundimonas species. The levels of DNA relatedness among $B$. vesicularis strains varied between 52 and $68 \%$. B. diminuta strains yielded values that ranged from 41 to $73 \%$. Genotypic species delineation became rather clear because of the low to moderate degrees of DNA binding among $B$. vesicularis strains, $B$. diminuta strains, and Brevundimonas sp. strains LMG 9564, LMG 9567ti, and LMG 11070 and because no significant DNA binding was measured between strain LMG 11050 and any of the other strains studied.

The results of a numerical analysis of phenotypic data corresponded well with the genotypic data. Homogeneous, separate phenotypic clusters were obtained for $B$. diminuta and $B$. vesicularis. Strains LMG 9564, LMG 9567t1, and LMG 11070 were closely linked to the $B$. vesicularis cluster, while strain LMG 11050 was significantly different (Fig. 3). Table 3 shows an overview of the distinguishing phenotypic features for members of the genus Brevundimonas. Numerical analyses of fatty acid patterns and protein profiles (Fig. 1 and 2) in general revealed separate clusters for $B$. diminuta and $B$. vesicularis. However, in both cases the three Brevundimonas sp. strains (LMG 9564, LMG 11070, and LMG 9567t1) and strain LMG 11050 grouped with the $B$. vesicularis strains. Except for two strains when the protein electrophoretic approach was used, a 
TABLE 4. DNA base compositions of strains and $T_{m(e)}$ values of DNA-rRNA hybrids

\begin{tabular}{|c|c|c|c|}
\hline \multirow[b]{2}{*}{ Strain } & \multirow{2}{*}{$\begin{array}{l}\mathrm{G}+\mathrm{C} \text { content } \\
\quad(\mathrm{mol} \%)\end{array}$} & \multicolumn{2}{|c|}{$T_{m(e)}\left({ }^{\circ} \mathrm{C}\right)$ of hybrid with rRNA from: } \\
\hline & & 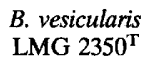 & $\begin{array}{l}\text { S. paucimobilis } \\
\text { LMG } 1227^{\mathrm{T}}\end{array}$ \\
\hline B. vesicularis $\mathrm{LMG} 2350^{\mathrm{T}}$ & 65.4 & 81.3 & 63.1 \\
\hline B. vesicularis LMG 9566 & 66.3 & 79.3 & \\
\hline B. vesicularis LMG 11067 & 65.4 & 81.1 & 63.1 \\
\hline B. vesicularis LMG 11148 & 66.0 & 81.1 & 63.1 \\
\hline B. vesicularis LMG 9554 & 65.6 & 81.4 & \\
\hline B. diminuta $\mathrm{LMG} 2089 \mathrm{t} 1^{\mathrm{T}}$ & 65.9 & 77.5 & 64.4 \\
\hline B. diminuta LMG 1798 & 66.5 & 77.2 & \\
\hline B. diminuta LMG 3503 & 67.3 & & \\
\hline B. diminuta LMG 10743 & 67.9 & 75.9 & \\
\hline B. diminuta LMG 11061 & 67.1 & 78.0 & \\
\hline B. diminuta LMG 11064 & 66.0 & 76.5 & \\
\hline B. diminuta LMG 11065 & 67.1 & 76.9 & \\
\hline Brevundimonas sp. strain LMG 9564 & 66.4 & 79.3 & \\
\hline Brevundimonas sp. strain LMG 9567t1 & 66.3 & 81.1 & \\
\hline Brevundimonas sp. strain LMG 11070 & 67.0 & 81.4 & \\
\hline Brevundimonas-like strain LMG 11050 & & 73.9 & \\
\hline S. paucimobilis $\mathrm{LMG} 1227^{\mathrm{T}}$ & $65.4^{a}$ & 63.2 & $80.6^{a}$ \\
\hline$[S$.$] capsulata \mathrm{LMG} 2830^{\mathrm{T}}$ & $65.9^{a}$ & & $71.1^{a}$ \\
\hline S. adhaesiva LMG $10922^{\mathrm{T}}$ & $67.9^{a}$ & & $75.2^{a}$ \\
\hline S. parapaucimobilis LMG $10923^{\mathrm{T}}$ & $66.9^{a}$ & & $79.5^{a}$ \\
\hline S. sanguis LMG $10925^{\mathrm{T}}$ & $66.2^{a}$ & & $79.7^{a}$ \\
\hline$S$. terrae LMG $10924^{\mathrm{T}}$ & $65.2^{a}$ & & $79.0^{a}$ \\
\hline [S.] yanoikuyae LMG $11252^{\mathrm{T}}$ & $63.7^{a}$ & & $72.2^{a}$ \\
\hline [S.] yanoikuyae LMG 9552 & 65.0 & & 72.7 \\
\hline [S.] yanoikuyae LMG 11066 & 63.2 & 65.1 & 71.8 \\
\hline Rhizomonas-Sphingomonas-like strain LMG 9555 & 65.3 & 64.0 & 71.6 \\
\hline Rhizomonas-Sphingomonas-like strain LMG 11049 & 64.2 & 65.1 & 71.8 \\
\hline Rhizomonas-Sphingomonas-like strain LMG 11069 & 63.4 & 63.8 & 71.1 \\
\hline "[P.] riboflavina" LMG $2277^{\mathrm{T}}$ & 61.5 & 64.0 & 64.2 \\
\hline$[P$.$] echinoides \mathrm{LMG} 2181^{\mathrm{T}}$ & 65.3 & 64.1 & 74.2 \\
\hline
\end{tabular}

${ }^{a}$ Data from reference 34 .

distinct homogeneous cluster was obtained for all $B$. diminuta strains. The presence of high percentages of the fatty acid 19:0 cyclo $\omega 8 \mathrm{c}$ is characteristic of $B$. diminuta strains. The two recognized Brevundimonas species were also easily differentiated by their polyamine contents (Table 5).

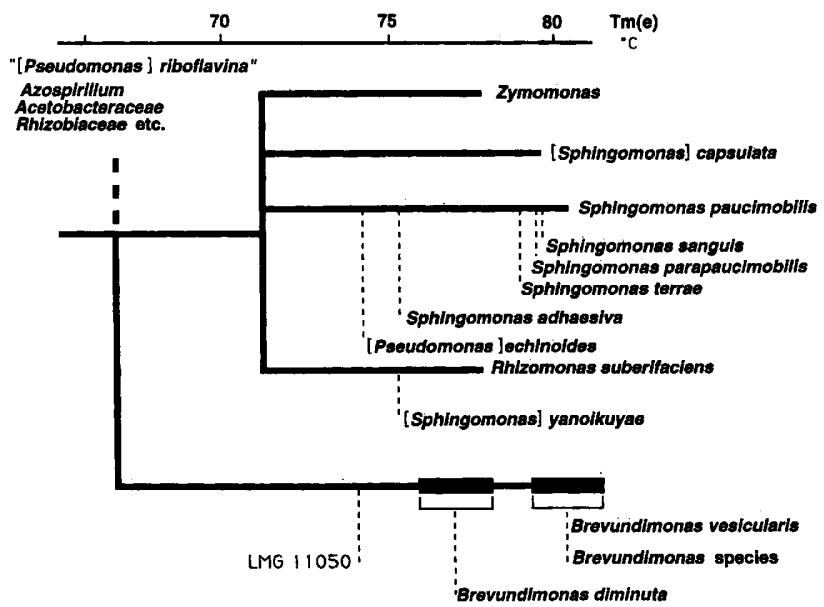

FIG. 5. Simplified rRNA dendrogram based on the $T_{m(e)}$ values of DNA-rRNA hybrids obtained with members of rRNA superfamily IV (the $\alpha$ subclass of the Proteobacteria). The data used are from this study and from reference 34 .
Reference strains of most Sphingomonas and Rhizomonas species were included in this study because several of the strains studied (e.g., some EF group 21 strains) were phenotypically similar to members of these genera. The taxonomy of these genera is complex and continuously changing $(11,22$, $32,34)$. Reclassification of $[S$. ] yanoikuyae in the genus $R h i-$ zomonas is probably correct (34). Moreover, [S.] capsulata, which was located on a separate rRNA branch, may be the core of a new genus. DNA-rRNA hybridization experiments revealed that the authentic Sphingomonas species are located on a separate rRNA branch (Fig. 5), and from this study it is clear that all of these species have a rather characteristic polyamine content (Table 5). All genotypic and phenotypic data confirmed that three strains (LMG 9552, LMG 9553, and LMG 11066) belong to [S.] yanoikuyae. As mentioned above, four strains (LMG 9555, LMG 11049, LMG 11069, and LMG 11151) were placed at the lower border of the $S$. paucimobilis rRNA branch and could, until now, not be classified in a particular genus. Two of these strains (LMG 9555 and LMG 11151) are phenotypically and chemotaxonomically very similar and probably should be classified in a new genus. However, we prefer to regard all four strains as Sphingomonas-Rhizomonas-like strains because the limited number of strains available does not allow reliable taxonomic descriptions.

In conclusion, on the basis of genotypic and phenotypic criteria, the genus Brevundimonas differs from its relatives, and separate generic status is justified. DNA-DNA hybridization studies revealed that there are at least two different species in 
TABLE 5. Polyamine contents of strains

\begin{tabular}{|c|c|c|c|c|}
\hline \multirow{2}{*}{ Taxon } & \multirow{2}{*}{$\begin{array}{l}\text { No. of strains } \\
\text { tested }\end{array}$} & \multicolumn{3}{|c|}{ Polyamine content $(\mu \mathrm{mol} / \mathrm{g}[\mathrm{wet} \mathrm{wt}])^{a}$} \\
\hline & & HSPD & SPD & Other polyamines $^{b}$ \\
\hline B. diminuta & 19 & $1.7-3.4$ & $\operatorname{tr}^{c}$ & \\
\hline B. vesicularis ${ }^{d}$ & 9 & $0.1-0.6$ & $1.6-2.5$ & NORSPD (4), PUT (1), SPM (1) \\
\hline Brevundimonas sp. strain LMG 9564 & & & 4.2 & \\
\hline Brevundimonas sp. strain LMG 9567t1 & & 0.6 & 2.9 & PUT \\
\hline Brevundimonas sp. strain LMG 11070 & & 0.6 & 3.8 & PUT \\
\hline Brevundimonas-like strain LMG 11050 & & 2.4 & 1.5 & NORSPD \\
\hline S. paucimobilis LMG $1227^{\mathrm{T}}$ & & 4.8 & $\operatorname{tr}$ & \\
\hline S. parapaucimobilis LMG $10923^{\mathrm{T}}$ & & 5.0 & $\operatorname{tr}$ & \\
\hline S. sanguis LMG $10925^{\mathrm{T}}$ & & 4.8 & $\operatorname{tr}$ & \\
\hline S. terrae LMG $10924^{\mathrm{T}}$ & & 3.5 & $\operatorname{tr}$ & \\
\hline S. adhaesiva LMG $10922^{\mathrm{T}}$ & & 1.8 & & \\
\hline [S.] capsulata LMG $2830^{\mathrm{T}}$ & & & 2.5 & NORSPD, PUT, DAP \\
\hline [S.] yanoikuyae & 4 & & $2.9-4.0$ & NORSPD (1), SPM (1), PUT (1) \\
\hline Rhizomonas-Sphingomonas-like strain LMG 11069 & & & 3.2 & \\
\hline Rhizomonas-Sphingomonas-like strain LMG 11049 & & & & NORSPD \\
\hline Rhizomonas-Sphingomonas-like strains & 2 & & $2.7-3.1$ & $\mathrm{CAD}(1)$ \\
\hline
\end{tabular}

a Abbreviations: HSPD, homospermidine; SPD, spermidine; NORSPD, norspermidine; PUT, putrescine; SPM, spermine; CAD, cadaverine.

${ }^{b}$ Some strains contain traces of other polyamines. The numbers in parentheses are the numbers of strains that produce the polyamines indicated.

${ }^{c}$ tr, trace.

${ }^{d}$ Strain LMG 9554 differs from the other $B$. vesicularis strains in that it produces only $0.6 \mu \mathrm{mol}$ of spermidine per $\mathrm{g}$ (wet weight) and no homospermidine.

the genus. The genus and species descriptions below are based on the data described above and on previous data $(1,2,17,20$, 24).

Description of Brevundimonas gen. nov. Brevundimonas (Brev.un.di'mo.nas. L. adj. brevis, short; L. fem. n. unda, wave; Gr. monas, a unit, monad; M.L. fem. n. Brevundimonas, bacterium with short-wavelength flagella). Gram-negative short rods that are 1 to $4 \mu \mathrm{m}$ long and $0.5 \mu \mathrm{m}$ in diameter. Motile by means of one polar flagellum that has a short wavelength $(0.6$ to $1 \mu \mathrm{m})$. Oxidase and catalase positive. Indole is not formed. Pantothenate, biotin, and cyanocobalamin are required as growth factors. Aerobic with a respiratory type of metabolism (Q10 is an intermediate electron carrier); never fermentative. Growth occurs on blood media at 30 and $37^{\circ} \mathrm{C}$. No growth occurs at $4^{\circ} \mathrm{C}$, and no autotrophic growth occurs with $\mathrm{H}_{2}$. Poly- $\beta$-hydroxybutyrate is accumulated as reserve material and is not hydrolyzed extracellularly. Acid is produced from primary alcohols by all strains that can utilize alcohols. Lecithinase (egg yolk) and lipase (Tween 80) are not produced. Gelatin is not liquefied. The strains exhibit a limited nutritional spectrum; only DL- $\beta$-hydroxybutyrate, pyruvate, $L$ glutamate, and L-proline are used by $90 \%$ or more of the strains as sole carbon and energy sources.

As determined by API galleries, the following substrates are used by none of the strains or by at most $10 \%$ of the strains (although some of these characteristics are useful for differentiating between named and unnamed strains [Table 3]): glycerol, erythritol, D-arabinose, L-arabinose, D-ribose, D-xylose, L-xylose, adonitol, methyl- $\beta$-xyloside, D-fructose, D-mannose, L-sorbose, dulcitol, inositol, mannitol, sorbitol, methyl- $\alpha-\mathrm{D}-$ mannoside, methyl- $\alpha$-D-glucose, $N$-acetylglucosamine, amygdalin, arbutin, salicin, lactose, D-melibiose, sucrose, trehalose,

TABLE 6. Differentiation of the genus Brevundimonas and phenotypically similar taxa ${ }^{a}$

\begin{tabular}{|c|c|c|c|c|c|c|c|c|c|}
\hline Taxon & Flagellation & Pigments & $\begin{array}{l}\text { Carbon } \\
\text { assimila- } \\
\text { tion }\end{array}$ & $\begin{array}{l}\text { Sphingo- } \\
\text { lipids }\end{array}$ & $\begin{array}{l}\text { Characteristic } \\
\text { hydroxy fatty } \\
\text { acid(s) }\end{array}$ & $\begin{array}{l}\text { Major poly- } \\
\text { amines }^{b}\end{array}$ & $\begin{array}{l}\text { Ubiqui- } \\
\text { none }^{b}\end{array}$ & $\begin{array}{c}\mathrm{G}+\mathrm{C} \\
\text { content } \\
(\mathrm{mol} \%)\end{array}$ & $\begin{array}{l}\text { Subclass } \\
\text { of Pro- } \\
\text { teobac- } \\
\text { teria }\end{array}$ \\
\hline Brevundimonas & $\begin{array}{l}\text { Polar, short } \\
\text { wavelength }\end{array}$ & $\begin{array}{l}\text { None, orange, or } \\
\text { yellow }\end{array}$ & Restricted & $\mathrm{ND}^{c}$ & $12: 03 \mathrm{OH}$ & SPD, HSPD & Q10 & $65-68$ & $\alpha-2$ \\
\hline $\begin{array}{l}\text { Sphingomonas and } \\
\text { Rhizomonas }\end{array}$ & Polar & $\begin{array}{l}\text { Deep yellow or } \\
\text { whitish brown }\end{array}$ & Normal & + & $14: 02 \mathrm{OH}$ & HSPD, SPD & Q10 & $59-68$ & $\alpha-4$ \\
\hline $\begin{array}{l}\text { Authentic genus } \\
\text { Pseudomonas }\end{array}$ & $\begin{array}{l}\text { Polar, long } \\
\text { wavelength }\end{array}$ & $\begin{array}{l}\text { None, fluorescent, } \\
\text { or yellow-or- } \\
\text { ange }\end{array}$ & Normal & ND & $\begin{array}{l}10: 03 \mathrm{OH}, 12: 0 \\
3 \mathrm{OH}\end{array}$ & PUT, SPD & Q9 & $59-68$ & $\gamma-3$ \\
\hline Comamonadaceae & $\begin{array}{l}\text { Polar or peri- } \\
\text { trichous }\end{array}$ & None or yellow & Restricted & ND & $10: 03 \mathrm{OH}^{d}$ & PUT, HPUT & Q8 & $60-69$ & $\beta-1$ \\
\hline Burkholderia & Polar & $\begin{array}{l}\text { Various (yellow, } \\
\text { orange, or red- } \\
\text { brown) }\end{array}$ & Normal & ND & $\begin{array}{l}14: 03 \mathrm{OH}, 16: 0 \\
3 \mathrm{OH}\end{array}$ & PUT, HPUT & Q8 & $64-68$ & $\beta-3$ \\
\hline Caulobacter & $\begin{array}{l}\text { Prosteca or } \\
\text { polar }\end{array}$ & $\begin{array}{l}\text { None or yellow to } \\
\text { golden red }\end{array}$ & Normal & ND & ND & ND & ND & $62-67$ & $\alpha-2$ \\
\hline
\end{tabular}

\footnotetext{
${ }^{a}$ Data from this study and references $23,24,27,31,32,34,39,43$, and 44 .

${ }^{b}$ Abbreviations: SPD, spermidine; HSPD, homospermidine; PUT, putrescine; HPUT, hydroxyputrescine; Q8, Q9, and Q10, ubiquinones with 8, 9, and 10 isoprene units, respectively.

${ }^{c} \mathrm{ND}$, not determined.

${ }^{d}$ Not present in some species (e.g., Hydrogenophaga palleronii) (23).
} 
inulin, D-melezitose, D-raffinose, glycogen, xylitol, $\beta$-gentiobiose, D-turanose, D-lyxose, D-tagatose, D-fucose, L-fucose, Darabitol, L-arabitol, gluconate, 2-ketogluconate, 5-ketogluconate, propionate, isobutyrate, heptanoate, $n$-caproate, caprylate, pelargonate, caprate, oxalate, malonate, maleate, glutarate, adipate, pimelate, suberate, azelate, sebacate, glycolate, D-malate, DL-glycerate, D-tartrate, L-tartrate, meso-tartrate, levulinate, citraconate, itaconate, mesaconate, citrate, phenylacetate, benzoate, $o$-hydroxybenzoate, $m$-hydroxybenzoate, $p$-hydroxybenzoate, D-mandelate, L-mandelate, phthalate, isophthalate, terephthalate, glycine, L-norleucine, DL-2-aminobutyrate, L-cysteine, L-methionine, L-phenylalanine, D-tryptophan, L-tryptophan, trigonelline, L-ornithine, L-lysine, L-citrulline, DL-kynurenine, betaine, creatine, $\beta$-alanine, DL-3aminobutyrate, DL-4-aminobutyrate, DL-5-aminovalerate, 2aminobenzoate, 3-aminobenzoate, 4-aminobenzoate, urea, acetamide, sarcosine, ethylamine, butylamine, amylamine, ethanolamine, benzylamine, diaminobutane, spermine, histamine, tryptamine, and glucosamine.

In addition, the following substrates are not used: ethyleneglycol, propyleneglycol, 2,3-butyleneglycol, eicosanedioate, benzoylformate, phenylethanediol, naphthalene, phenol, quinate, testosterone, kynurenate, anthranilate, hippurate, nicotinate, saccharate, mucate, DL- $\alpha$-aminovalerate, methylamine, $n$-dodecane, $n$-hexadecane, methanol, isopropanol, $n$-butanol, isobutanol, and geraniol.

The following enzyme activities are always present, as determined by API ZYM tests: alkaline and acid phosphatase, ester lipase (C8) (except Brevundimonas sp. strain LMG 9567t1), leucine arylamidase, trypsin, and phosphoamidase.

The following enzyme activities are always absent, as determined by API ZYM tests: lipase (C14), cystine arylamidase, $\alpha$-galactosidase, $\beta$-galactosidase, $\beta$-glucosidase (can be used to differentiate the unnamed Brevundimonas sp. [Table 3]), $N$-acetyl- $\beta$-glucosidase, $\alpha$-mannosidase, and $\alpha$-fucosidase.

Negative reactions are also obtained for lysine and ornithine decarboxylase, urease, arginine dihydrolase, and phenylalanine deaminase.

The genus belongs to the $\alpha$ subclass of the Proteobacteria; it constitutes a separate rRNA branch that is equidistant from the rRNA clusters consisting of the family Acetobacteraceae, the genus Rhodobacter, the Rhodospirillum-Azospirillum group, the Bradyrhizobium-Rhodopseudomonas group, the Agrobacterium-Rhizobium group, and the Sphingomonas-Rhizomonas group. The closest natural relatives are organisms that are now classified as members of the genus Caulobacter. Nitrate is not reduced or is rarely reduced. All strains are characterized by two major fatty acids, 16:0 and 18:1 (summed feature 7) and the following minor components: $12: 03 \mathrm{OH}, 14: 0,15: 0,16: 1$, $17: 0,17: 1$, and an unknown fatty acid with an equivalent chain length of 18.080. Isolated from water and clinical specimens. The $\mathrm{G}+\mathrm{C}$ contents range from 65 to $68 \mathrm{~mol} \%$. The type species is Brevundimonas diminuta.

Description of Brevundimonas diminuta (Leifson and Hugh 1954) comb. nov. The description of Brevundimonas diminuta (di.mi.nu' ta. L. adj. minutus, small, defective, minute) is the same as that given above for the genus, with the following additional characteristics. Cystine is a growth factor.

As determined by API galleries, the substrates that are used by $90 \%$ or more of the strains are acetate, butyrate, L-leucine, L-serine, L-histidine, DL-norvaline, and L-aspartate. The substrates that are used by none of the strains or by at most $10 \%$ of the strains are D-galactose, D-glucose, L-rhamnose, D-cellobiose, maltose, starch, DL-lactate, and aconitate. The substrates that are used by some strains (the reactions of the type strain are indicated in parentheses) are isovalerate (positive), $n$ valerate (positive), succinate (negative), fumarate (negative), L-malate (negative), 2-ketoglutarate (negative), $\mathrm{D}-\alpha$-alanine (negative), L-alanine (negative), L-isoleucine (positive), L-valine (negative), L-norleucine (negative), DL-norvaline (positive), L-threonine (positive), L-tyrosine (negative), and L-arginine (negative).

Esculin is not hydrolyzed. Negative for valine arylamidase and $\alpha$-glucosidase activities. Chymotrypsin activity is present in some strains, including the type strain. The levels of DNA relatedness range from 41 to $100 \%$. On tryptic soy agar, homospermidine is the major cellular polyamine component. Strains are characterized by the presence of high percentages of 19:0 cyclo $\omega 8 \mathrm{c}$. The type strain is LMG 2089 (= ATCC $11568=$ CCUG 1427). The $\mathrm{G}+\mathrm{C}$ content is 66 to $68 \mathrm{~mol} \%$.

Description of Brevundimonas vesicularis (Büsing, Döll, and Freytag 1953) comb. nov. The description of Brevundimonas vesicularis (ve.si.cu.la'ris. L. adj. vesicularis, pertaining to a vesicle) is the same as that given above for the genus, with the following additional characteristics.

As determined by API galleries, the substrates that are used by $90 \%$ or more of the strains are D-galactose, D-glucose, and maltose. The substrates that are used by none of the strains or by at most $10 \%$ of the strains tested are $n$-valerate, isovalerate, 2-ketoglutarate, L-isoleucine, $N$-norleucine, L-valine, L-tyrosine, $\mathrm{L}$-histidine, and $\mathrm{L}$-arginine. The substrates that are used by some strains (the reactions of the type strain are indicated in parentheses) are starch (positive), rhamnose (negative), D-cellobiose (positive), acetate (negative), butyrate (positive), succinate (positive), fumarate (positive), DL-lactate (positive), L-malate (positive), aconitate (negative), D- $\alpha$-alanine (negative), L-alanine (negative), L-leucine (negative), DL-norvaline (negative), L-serine (negative), L-threonine (negative), and L-aspartate (negative).

Esculin is hydrolyzed. Positive for $\alpha$-glucosidase activity and negative for chymotrypsin activity. Valine arylamidase is present in some strains but not the type strain.

Some strains can be distinguished from $B$. diminuta by the oxidation of glucose, xylose, and maltose, the failure to produce a pellicule in broth cultures, and the production of an intracellular carotenoid pigment. The levels of DNA relatedness range from 50 to $100 \%$. On tryptic soy agar, spermidine is the major polyamine component. The type strain is LMG 2350 (= ATCC $11426=$ CCUG 2032). The G+C content is 65 to 66 mol\%.

\section{ACKNOWLEDGMENTS}

P.D. is indebted to the Belgian National Fund for Scientific Research for a position as Senior Research Associate. K.K. is indebted to the Fund for Medical Scientific Research (Belgium) for research and personal grants. Part of this research was performed in the framework of CEC BRIDGE project BIOT-CT91-0294.

We thank T. O. MacAdoo for advice concerning the Latin names.

\section{REFERENCES}

1. Ballard, R. W., M. Doudoroff, and R. Y. Stanier. 1968. Taxonomy of the aerobic pseudomonads: Pseudomonas diminuta and $P$. vesicularis. J. Gen. Microbiol. 53:349-361.

2. Büsing, K. H., W. Döll, and K. Freytag. 1953. Die Bakterienflora der medizinische Blutegel. Arch. Mikrobiol. 19:52-86.

3. Busse, J., and G. Auling. 1988. Polyamine pattern as a chemotaxonomic marker within the Proteobacteria. Syst. Appl. Microbiol. 11:1-8.

4. Byng, G. S., J. L. Johnson, R. J. Whitaker, R. L. Gherna, and R. A. Jensen. 1983. The evolutionary pattern of aromatic amino acid 
biosynthesis and the emerging phylogeny of pseudomonad bacteria. J. Mol. Evol. 19:272-282.

5. De Ley, J. 1970. Reexamination of the association between melting point, buoyant density, and chemical base composition of deoxyribonucleic acid. J. Bacteriol. 101:738-754.

6. De Ley, J. 1992. The Proteobacteria: ribosomal RNA cistron similarities and bacterial taxonomy, p. 2111-2140. In A. Balows, H. G. Trüper, M. Dworkin, W. Harder, and K.-H. Schleifer (ed.), The prokaryotes, vol. 2. Springer-Verlag, New York.

7. De Ley, J., H. Cattoir, and A. Reynaerts. 1970. The quantitative measurement of DNA hybridization from renaturation rates. Eur. J. Biochem. 12:133-142.

8. De Ley, J., and J. De Smedt. 1975. Improvements on the membrane filter method for DNA:rRNA hybridization. Antonie van Leeuwenhoek J. Microbiol. Serol. 41:287-307.

9. De Ley, J., and R. Tytgat. 1970. Evaluation of membrane filter methods for DNA-DNA hybridizations. Antonie van Leeuwenhoek J. Microbiol. Serol. 36:461-474.

10. De Ley, J., and J. Van Muylem. 1963. Some applications of deoxyribonucleic acid base composition in bacterial taxonomy. Antonie van Leeuwenhoek J. Microbiol. Serol. 29:344-358.

11. Denner, E., W. Lubitz, and H. J. Busse. 1993. Description of Chromobacterium folium as a strain of the species Sphingomonas yanoikuyae, p. 76. Abstr. FEMS Meet. Identification Bacteria. Present Trends Future Prospects.

12. De Vos, $\mathbf{P}$., and J. De Ley. 1983. Intra- and intergeneric similarities of Pseudomonas and Xanthomonas ribosomal ribonucleic acid cistrons. Int. J. Syst. Bacteriol. 33:487-509.

13. De Vos, P., M. Goor, M. Gillis, and J. De Ley, 1985. Ribosomal ribonucleic acid cistron similarities of Pseudomonas species. Int. J. Syst. Bacteriol. 35:169-184.

14. De Vos, P., A. Van Landschoot, P. Segers, R. Tytgat, M. Gillis, M. Bauwens, R. Rossau, M. Goor, B. Pot, K. Kersters, P. Lizzaraga, and J. De Ley. 1989. Genotypic relationships and taxonomic localization of unclassified Pseudomonas and Pseudomonas-like strains by deoxyribonucleic acid-ribosomal ribonucleic acid hybridizations. Int. J. Syst. Bacteriol. 39:35-49.

15. Falsen, E. 1989. Catalogue of strains. Culture Collection, University of Göteborg, Göteborg, Sweden.

16. Gilardi, G. L. 1978. Identification of Pseudomonas and related bacteria, p. 15-44. In G. L. Gilardi (ed.), Glucose nonfermenting Gram-negative bacteria in clinical microbiology. CRC Press, Inc., Boca Raton, Fla.

17. Gilardi, G. L. 1991. Pseudomonas and related genera, p. 429-441. In A. Balows, W. J. Hausler, Jr., K. L. Herrmann, H. D. Isenberg, and H. J. Shadomy (ed.), Manual of clinical microbiology, 5th ed. American Society for Microbiology, Washington, D.C.

18. Gillis, M., and B. Reinhold-Hurek. 1994. Taxonomy of Azospirillum, p. 1-14. In J. Okon (ed.), Azospirillum/plant associations. CRC Press, Inc., Boca Raton, Fla.

19. Kersters, K., K.-H. Hinz, A. Hertle, P. Segers, A. Lievens, O. Siegmann, and J. De Ley. 1984. Bordetella avium sp. nov., isolated from the respiratory tracts of turkeys and other birds. Int. J. Syst. Bacteriol. 34:56-70.

20. Leifson, E., and R. Hugh. 1954. A new type of polar monotrichous flagellation. J. Gen. Microbiol. 10:68-70.

21. Marmur, J. A. 1961. A procedure for the isolation of deoxyribonucleic acid from micro-organisms. J. Mol. Biol. 3:208-218.

22. Moore, E. R. B., R.-M. Wittich, P. Fortnagel, and K. N. Timmis. 1993. 16S ribosomal RNA gene sequence characterization and phylogenetic analysis of a dibenzo-p-dioxin-degrading isolate within the new genus Sphingomonas. Lett. Appl. Microbiol. 17: 115-118.

23. Oyaizu, H., and K. Komogata. 1983. Grouping of Pseudomonas species on the basis of cellular fatty acid composition and the quinone system with special reference to the existence of 3-hydroxy fatty acids. J. Gen. Appl. Microbiol. 29:17-40.

24. Palleroni, N. J. 1984. Genus I. Pseudomonas Migula 1894, p. 141-199. In N. R. Krieg and J. G. Holt (ed.), Bergey's manual of systematic bacteriology, vol. 1. The Williams \& Wilkins Co., Baltimore.

25. Palleroni, N. J., and J. F. Bradbury. 1993. Stenotrophomonas, a new bacterial genus for Xanthomonas maltophilia (Hugh 1980)
Swings et al. 1983. Int. J. Syst. Bacteriol. 43:606-609.

26. Palleroni, N. J., T. Kunisawa, R. Contopoulou, and M. Doudoroff. 1973. Nucleic acid homologies in the genus Pseudomonas. Int. J. Syst. Bacteriol. 23:333-339.

27. Pointdexter, J. S. 1989. Genus Caulobacter Henrici and Johnson 1935, p. 1924-1939. In J. T. Staley, M. P. Bryant, N. Pfennig, and J. G. Holt (ed.), Bergey's manual of systematic bacteriology, vol. 3 . The Williams \& Wilkins Co., Baltimore.

28. Sneath, P. H. A., and R. R. Sokal. 1973. Numerical taxonomy. The principles and practice of numerical classification. W. H. Freeman and Co., San Francisco.

29. Sokal, R. R., and C. D. Michener. 1958. A statistical method for evaluating systematic relationships. Univ. Kans. Sci. Bull. 38:14091438.

30. Stahl, D. A., R. Key, F. Flesher, and J. Smit. 1992. The phylogeny of marine and freshwater caulobacters reflects their habitat. J. Bacteriol. 174:2193-2198.

31. Stead, D. E. 1992. Grouping of plant-pathogenic and some other Pseudomonas spp. by using cellular fatty acid profiles. Int. J. Syst. Bacteriol. 42:281-295.

32. Takeuchi, M., F. Kawai, Y. Shimada, and A. Yokota. 1993. Taxonomic study of polyethylene glycol-utilizing bacteria: emended description of the genus Sphingomonas and new descriptions of Sphingomonas macrogoltabidus sp. nov., Sphingomonas sanguis sp. nov. and Sphingomonas terrae sp. nov. Syst. Appl. Microbiol. 16:227-238.

33. Tamaoka, J., D.-M. Ha, and K. Komagata. 1987. Reclassification of Pseudomonas acidovorans den Dooren de Jong 1926 and Pseudomonas testosteroni Marcus and Talalay 1956 as Comamonas acidovorans comb. nov. and Comamonas testosteroni comb. nov., with an emended description of the genus Comamonas. Int. J. Syst. Bacteriol. 37:52-59.

34. van Bruggen, A. H. C., K. N. Jochimsen, E. M. Steinberger, P. Segers, and M. Gillis. 1993. Classification of Rhizomonas suberifaciens, an unnamed Rhizomonas species, and Sphingomonas spp. in rRNA superfamily IV. Int. J. Syst. Bacteriol. 43:1-7.

35. Vauterin, L., J. Swings, and K. Kersters. 1991. Grouping of Xanthomonas campestris pathovars by SDS-PAGE of proteins. J. Gen. Microbiol. 137:1677-1687.

36. Vauterin, L., and P. Vauterin. 1992. Computer aided objective comparison of electrophoresis patterns for grouping and identification of microorganisms. Eur. Microbiol. 1:37-41.

37. Vauterin, L., P. Yang, B. Hoste, M. Vancanneyt, E. L. Civerolo, J. Swings, and K. Kersters. 1991. Differentiation of Xanthomonas campestris pv. citri strains by sodium dodecyl sulfate-polyacrylamide gel electrophoresis of proteins, fatty acid analysis, and DNA-DNA hybridization. Int. J. Syst. Bacteriol. 41:535542.

38. Willems, A., J. Busse, M. Goor, B. Pot, E. Falsen, E. Jantzen, B. Hoste, M. Gillis, K. Kersters, G. Auling, and J. De Ley. 1989. Hydrogenophaga, a new genus of hydrogen-oxidizing bacteria that includes Hydrogenophaga flava comb. nov. (formerly Pseudomonas flava), Hydrogenophaga palleronii (formerly Pseudomonas palleronii), Hydrogenophaga pseudoflava (formerly Pseudomonas pseudoflava and "Pseudomonas carboxydoflava"), and Hydrogenophaga taeniospiralis (formerly Pseudomonas taeniospiralis). Int. J. Syst. Bacteriol. 39:319-333.

39. Willems, A., J. De Ley, M. Gillis, and K. Kersters. 1991. Comamonadaceae, a new family encompassing the acidovorans rRNA complex, including Variovorax paradoxus gen. nov., comb. nov. for Alcaligenes paradoxus (Davis 1969). Int. J. Syst. Bacteriol. 41:445-450.

40. Willems, A., E. Falsen, B. Pot, E. Jantzen, B. Hoste, P. Vandamme, M. Gillis, K. Kersters, and J. De Ley. 1990. Acidovorax, a new genus for Pseudomonas facilis, Pseudomonas delafieldii E. Falsen (EF) group 13, EF group 16, and several clinical isolates, with the species Acidovorax facilis comb. nov., Acidovorax delafieldii comb. nov., and Acidovorax temperans sp. nov. Int. J. Syst. Bacteriol. 40:384-398.

41. Wishart, D. 1978. Clustan user's manual, 3rd ed. Program Library Unit, Edinburgh University, Edinburgh.

42. Woese, C. R., P. Blanz, and C. M. Hahn. 1984. What isn't a pseudomonad: the importance of nomenclature in bacterial clas- 
sification. Syst. Appl. Microbiol. 5:179-195.

43. Yabuuchi, E., Y. Kosako, H. Oyaizu, I. Yano, H. Hotta, Y. Hashimoto, T. Ezaki, and M. Arakawa. 1992. Proposal of Burkholderia gen. nov. and transfer of seven species of the genus Pseudomonas homology group II to the new genus with the type species Burkholderia cepacia (Palleroni and Holmes 1981) comb. nov. Microbiol. Immunol. 36:1251-1275.

44. Yabuuchi, E., I. Yano, H. Oyaizu, Y. Hashimoto, T. Ezaki, and H.
Yamamoto. 1990. Proposals of Sphingomonas paucimobilis gen. nov. and comb. nov., Sphingomonas parapaucimobilis sp. nov., Sphingomonas yanoikuyae sp. nov., Sphingomonas adhaesiva sp. nov., Sphingomonas capsulata comb. nov. and two genospecies of the genus Sphingomonas. Microbiol. Immunol. 34:99-119.

45. Yang, P., P. De Vos, K. Kersters, and J. Swings. 1993. Polyamine patterns as chemotaxonomic markers for the genus Xanthomonas. Int. J. Syst. Bacteriol, 43:709-714. 